\title{
Detection of Eutypa lata and Eutypella vitis in Grapevine by Nested Multiplex Polymerase Chain Reaction
}

\author{
M. Catal, S. A. Jordan, S. C. Butterworth, and A. M. C. Schilder
}

Department of Plant Pathology, Michigan State University, East Lansing 48824.

Current address of S. C. Butterworth: 415 Lincoln Avenue, Dunellen, NJ 08812.

Accepted for publication 11 December 2006.

\begin{abstract}
Catal, M., Jordan, S. A., Butterworth, S. C., and Schilder, A. M. C. 2007. Detection of Eutypa lata and Eutypella vitis in grapevine by nested multiplex polymerase chain reaction. Phytopathology 97:737-747.

Two fungi were isolated from grapevines in Michigan vineyards with Eutypa dieback symptoms: Eutypa lata and Eutypella vitis. These fungi are difficult to distinguish morphologically but are genetically distinct as determined by sequencing of the internal transcribed spacer (ITS) regions. The ITS regions of 25 Eutypa lata and 15 Eutypella vitis isolates were sequenced. Eutypa lata sequences were more variable than those of Eutypella vitis. Polymerase chain reaction (PCR) primers were designed

for each species and evaluated against isolates of both fungi as well as 11 closely related Diatrypaceous fungi and 23 isolates of other fungi representing various pathogenic, saprophytic, and endophytic genera on grape and other small fruit crops. The primers were specific for their intended species. A nested multiplex PCR protocol was developed and used to successfully detect these fungi in wood samples from cankers with and without stromata from naturally infected vines as well as in artificially inoculated, potted canes. The primers developed in this study will assist in our abilities to diagnose and study the roles of Eutypa lata and Eutypella vitis in Eutypa dieback development.
\end{abstract}

Eutypa dieback, previously known as "dead-arm," affects grapevines (Vitis spp.) in countries around the world, including the United States, Europe, Australia, and South Africa (10). The disease is caused by the ascomycete fungus Eutypa lata (Pers.:Fr.) Tul. \& C. Tul (syn. E. armeniacae Hansf. \& Carter), which is also a pathogen of other woody plants, such as almond, apricot, cherry, olive, peach, and walnut $(8,11,24,34)$.

Infection occurs when windborne ascospores of the fungus land on fresh pruning wounds and invade the xylem vessels. Two to four years later, cankers become apparent around pruning cuts on trunks and cordons $(9,34)$. Foliar symptoms are most obvious early in the season and include yellowing and cupping of newly emerged leaves, stunted shoots with short internodes, and shedding of blossom clusters $(9,34)$. These symptoms are attributed to one or more toxins produced by the fungus $(17,36,52)$. Vines slowly decline and eventually die (56). After the bark weathers away from the cankered area, the fungus produces black stromata which contain numerous perithecia with infectious ascospores $(9,38)$. In Michigan, ascospores are released throughout the year, except during hot, dry periods in the summer (49).

Eutypa dieback is difficult to control and may lead to severe economic losses, primarily due to decreased yields and longevity of infected vines. Additional expenses include the removal or renewal of infected vines, replanting and regrafting, as well as a delay in the productivity of newly planted vines. Yield losses of 30 to $62 \%$ have been reported in California (37), where the disease is a major constraint to vineyard productivity. The cost to wine production in California has been estimated to be in excess of \$260 million per year (50). In Michigan, many older 'Concord' (Vitis labrusca L.) vineyards suffer from Eutypa dieback $(7,48)$. Foliar symptoms often are used by growers to identify infected vines for pruning or removal; however, these symptoms may be

Corresponding author: A. M. C. Schilder; E-mail address: schilder@msu.edu

doi:10.1094/PHYTO-97-6-0737

(C) 2007 The American Phytopathological Society variable from one season to the next $(7,48)$. In addition, healthy growth often obscures symptomatic shoots by midsummer (33), greatly reducing the ability of growers to monitor and manage the disease.

Single-ascospore isolations from perithecia found on dead wood of Concord vines in vineyards with Eutypa dieback in Michigan yielded two fungi in the family Diatrypaceae: E. lata and Eutypella vitis (Schwein.:Fr.) Ellis \& Everh. (syn. E. aequilinearis (Schwein.:Fr.) Starb.) (48). Fruiting structures of these fungi on wood and their ascospores appeared very similar. In addition, both fungi are white or creamy white in culture. The fungi were identified based on sequencing of the internal transcribed spacer (ITS) region (48) and morphological characteristics $(19,29,44)$. E. vitis previously was reported on wood of a Concord vine in Illinois (23). This particular isolate was also used as an "outgroup" in a study on diversity of Eutypa lata isolates in California (15). The United States National Fungal Herbarium contains two specimens of Eutypella vitis collected from Vitis spp. in Paw Paw, MI in 1907 and in Lawton, MI in 1908. Other specimens of this fungus in the herbarium originate from V. labrusca in Virginia; Vitis spp. in Maryland, South Carolina, Virginia, and Italy; V. rotundifolia Michx. in Alabama; and V. vinifera L. in Pakistan (information is available online from the Fungal Databases, Systematic Botany and Mycology Laboratory, Agricultural Research Service, United States Department of Agriculture). However, most of these specimens were collected in the early 1900 s, and no reference was made to any disease symptoms on the plant or the plant tissues on which they were found.

The pathogenicity of $E$. vitis on grape is unknown. Preliminary results with mycelium-inoculated Concord cuttings indicate that the fungus is able to colonize healthy grapevine tissue and cause necrosis similar to that caused by Eutypa lata isolates (30). Some isolates of this fungus were found to produce phytotoxic compounds $(30,35)$. Recently, two other Diatrypaceous fungi, $E$. leptoplaca (Mont.) Rappaz and Cryptovalsa ampelina (Nitschke) Fuckel, were characterized as necrotrophic pathogens on grape $(36,55)$, indicating the possibility that Eutypa dieback symptoms, 
or at least cankers, can be caused by fungi other than E. lata. If Eutypella vitis is found to be a primary pathogen of grape, it may differ from Eutypa lata in its symptomology and epidemiology, possibly requiring different management strategies. If, on the other hand, it is an opportunistic fungus growing on declining or dead grapevines, its confusion with E. lata could lead to false positive disease diagnoses. In either case, the ability to rapidly and reliably distinguish the two fungi in the laboratory as well as in the field becomes vitally important.

Isolation of the causal fungus from infected vines for diagnostic purposes may be complicated by the presence of saprophytic fungi in infected wood $(34,54)$. Antisera have been developed to distinguish $E$. lata from other fungi in culture and also in wood, but specificity has been a problem $(22,43)$. The use of species-specific primers in the polymerase chain reaction (PCR) has proved useful in the detection and identification of fungal pathogens, particularly those that are difficult to isolate or those that cause symptomless infection $(6,33,45)$. The sequences of the ITS regions of ribosomal DNA are most commonly utilized to design PCR primers for fungi. The ITS regions comprise two variable noncoding regions (ITS1 and ITS2) that separate the highly conserved $18 \mathrm{~S}$ (small subunit), $5.8 \mathrm{~S}$, and 28S (large subunit) ribosomal RNA genes. The ITS regions can be highly polymorphic among species within a genus $(25,49)$ and have been used to identify many important plant pathogens, including Fusarium (18, 51), Phytophthora (3), and Pythium (3) spp.
Multiplex PCR, a technique that utilizes multiple sets of primers, was first developed to assist in diagnosis of Duchenne muscular dystrophy (12), but since has been used extensively in the field of plant pathology. Although primarily used for the detection of pathogens directly from infected tissue $(4,14,21,27)$, the technique also has been used for race determination of pathogens $(13,15)$ and identification of mating types $(26,53)$.

A method combining the use of universal PCR primers with restriction fragment length polymorphisms (RFLP) was used by Rolshausen et al. (47) to distinguish E. lata from other fungi in culture. Lecomte et al. (32) designed species-specific primer pairs for E. lata and tested them successfully on numerous isolates from Italy, Spain, and France. However, Rolshausen et al. (47) found that some of these E. lata-specific primer sets also amplified DNA of several closely related Diatrypaceous fungi. More recently, a set of primers developed from sequence-characterized amplified regions was used to detect $E$. lata in inoculated vines in Australia (31). Although isolates of E. lata from Australia, New Zealand, Europe, and California were used to develop primers, few Diatrypaceous fungi and no isolates from other areas of the United States were tested; therefore, it is not known whether they will detect isolates from the eastern United States or can distinguish E. lata from Eutypella vitis. To our knowledge, no speciesspecific primers for $E$. vitis have been reported in the literature. The objective of this research was to develop a PCR-based

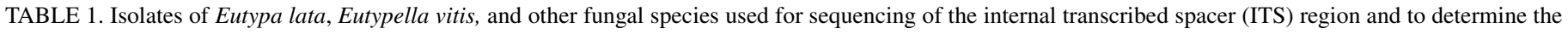
species specificity of primers EL1, EL4, EV1, and EV4 for polymerase chain reaction (PCR) amplification

\begin{tabular}{|c|c|c|c|c|c|c|}
\hline \multirow[b]{2}{*}{ Fungus, isolate ID } & \multirow[b]{2}{*}{ Host } & \multirow[b]{2}{*}{ Origin } & \multirow[b]{2}{*}{ GenBank number ${ }^{b}$} & \multicolumn{3}{|c|}{ PCR result ${ }^{\mathrm{a}}$} \\
\hline & & & & ITS1F, ITS4 & EL1, EL4 & EV1, EV4 \\
\hline Eutypa lata $\mathrm{E} 30^{\mathrm{c}}$ & Vitis sp. & California & AY462539 & + & + & - \\
\hline E. lata $\mathrm{E} 31^{\mathrm{c}}$ & Vitis sp. & California & AY462540 & + & + & - \\
\hline E. lata $\mathrm{E} 38^{\mathrm{c}}$ & Vitis sp. & California & AY462541 & + & + & - \\
\hline E. lata $\mathrm{MI}-3-25-1$ & Vitis labrusca 'Concord' & Lawton, MI & AY462542 & + & + & - \\
\hline E. lata MI-3-25-2 & V. labrusca 'Concord' & Lawton, MI & AY462543 & + & + & - \\
\hline E. lata MI-3-25-4 & V. labrusca 'Concord' & Lawton, MI & AY462544 & + & + & - \\
\hline E. lata $\mathrm{MI}-3-25-5$ & V. labrusca 'Concord' & Lawton, MI & AY462545 & + & + & - \\
\hline E. lata $\mathrm{MI}-3 \mathrm{~B}-1$ & V. labrusca 'Concord' & Berrien Springs, MI & AY462546 & + & + & - \\
\hline E. lata $\mathrm{MI}-3 \mathrm{~B}-2$ & V. labrusca 'Concord' & Berrien Springs, MI & AY462547 & + & + & - \\
\hline E. lata MI-7-1 & V. labrusca 'Concord' & Berrien Springs, MI & AY462548 & + & + & - \\
\hline E. lata $\mathrm{MI}-7-2$ & V. labrusca 'Concord' & Berrien Springs, MI & AY462549 & + & + & - \\
\hline E. lata MI-7-3 & V. labrusca 'Concord' & Berrien Springs, MI & AY462550 & + & + & - \\
\hline E. lata MI-7-5 & V. labrusca 'Concord' & Berrien Springs, MI & AY462551 & + & + & - \\
\hline E. lata MI-7-6 & V. labrusca 'Concord' & Berrien Springs, MI & AY462552 & + & + & - \\
\hline E. lata MI-7-7 & V. labrusca 'Concord' & Berrien Springs, MI & AY462553 & + & + & - \\
\hline E. lata $\mathrm{MI}-7-8$ & V. labrusca 'Concord' & Berrien Springs, MI & AY462554 & + & + & - \\
\hline E. lata MI-7-9 & V. labrusca 'Concord' & Berrien Springs, MI & AY462555 & + & + & - \\
\hline E. lata MI-7-10 & V. labrusca 'Concord' & Berrien Springs, MI & AY462556 & + & + & - \\
\hline E. lata MI-7-11 & V. labrusca 'Concord' & Berrien Springs, MI & AY462557 & + & + & - \\
\hline E. lata MI-7-12 & V. labrusca 'Concord' & Berrien Springs, MI & AY462558 & + & + & - \\
\hline E. lata MI-8-1 & V. labrusca 'Concord' & Baroda, MI & AY462559 & + & + & - \\
\hline E. lata MI-8-2 & V. labrusca 'Concord' & Baroda, MI & AY462560 & + & + & - \\
\hline E. lata MI-8-3 & V. labrusca 'Concord' & Baroda, MI & AY462561 & + & + & - \\
\hline E. lata $\mathrm{PA}-2^{\mathrm{c}}$ & Vitis sp. & Pennsylvania & AY462562 & + & + & - \\
\hline E. lata $\mathrm{PA}-4^{\mathrm{c}}$ & Vitis sp. & Pennsylvania & AY462563 & + & + & - \\
\hline Eutypella vitis MI-10-1 & V. labrusca 'Concord' & Baroda, MI & AY462564 & + & - & + \\
\hline E. vitis $\mathrm{MI}-2$ & V. labrusca 'Concord' & Lawton, MI & AY462565 & + & - & + \\
\hline E. vitis MI-2-1 & V. labrusca 'Concord' & Baroda, MI & AY462566 & + & - & + \\
\hline E. vitis MI-3-1 & V. labrusca 'Concord' & Berrien Springs, MI & AY462567 & + & - & + \\
\hline E. vitis MI-3A-1 & V. labrusca 'Concord' & Berrien Springs, MI & AY462568 & + & - & + \\
\hline E. vitis MI-3A-2 & V. labrusca 'Concord' & Berrien Springs, MI & AY462569 & + & - & + \\
\hline E. vitis MI-4-51-1 & V. labrusca 'Concord' & Lawton, MI & AY462570 & + & - & + \\
\hline E. vitis MI-4-51-10 & V. labrusca 'Concord' & Lawton, MI & AY462571 & + & - & + \\
\hline E. vitis MI-4-51-2 & V. labrusca 'Concord' & Lawton, MI & AY462572 & + & - & + \\
\hline
\end{tabular}

\footnotetext{
a Amplification product present (+) or absent (-).

b GenBank accession numbers of ITS sequences.

c Isolates provided by F. Trouillas and D. Gubler, University of California, Davis.

${ }^{\mathrm{d}}$ Previously sequenced by F. Trouillas and D. Gubler (55).

e Isolates provided by B. Hed, Lake Erie Regional Grape Research and Extension Center, North East, PA.

f Isolates provided by M. Ellis, Department of Plant Pathology, Ohio State University, Wooster.
} 
method to distinguish Eutypa lata and Eutypella vitis from grapevine, both in culture and in planta.

\section{MATERIALS AND METHODS}

Fungal culture collection and maintenance. Eutypa lata and Eutypella vitis isolates were obtained from three different Concord vineyards in southwest Michigan (Lawton, Baroda, and Berrien Springs). Vine trunks and branches with cankers having visible stromata were collected and brought back to the laboratory. Pieces of wood with perithecia were soaked in sterile water for 6 to $8 \mathrm{~h}$. Individual perithecia were transferred with sterile forceps to a microscope slide and crushed in $50 \mu \mathrm{l}$ of water by gently pressing the cover slip. The ascospore suspension was transferred to a 2-ml centrifuge tube and the spore concentration was determined with an improved Neubauer hemacytometer (American Optical Co., New York). The suspension then was diluted to $10^{2}$ and $10^{3}$ spores per $100 \mu \mathrm{l}$ and plated onto potato dextrose agar (PDA) amended with aqueous streptomycin sulfate (20 mg liter ${ }^{-1}$ ) to prevent bacterial growth. The plates were incubated at room temperature and checked daily for 4 days for fungal growth. Single-ascospore colonies were subcultured on the same medium. Fungal isolates from other geographic regions also were obtained for use in this study (Table 1). All isolates were stored in $15 \%$ glycerol at $-80^{\circ} \mathrm{C}$.
DNA extraction from cultures. For DNA extraction, fungal isolates were grown for 7 to 10 days on cellulose membranecovered plates. Mycelium was scraped off and placed into $1.5-\mathrm{ml}$ microcentrifuge tubes. DNA was extracted according to the protocol described by Lee et al. (33). Approximately $100 \mathrm{mg}$ of mycelium was suspended in $700 \mu$ of lysis buffer $(50 \mathrm{mM}$ Tris$\mathrm{HCI}, 50 \mathrm{mM}$ ethylenediaminetetraacetic acid [EDTA], 3\% sodium dodecyl sulfate [SDS], $\mathrm{pH} 8.0$; amended with $1 \%$ 2-mercaptoethanol just prior to each use). The mycelium was crushed with a pestle for 3 to $5 \mathrm{~min}$ and incubated for $1 \mathrm{~h}$ at $65^{\circ} \mathrm{C}$. Then, $700 \mu \mathrm{l}$ of phenol:chloroform:isoamyl alcohol (25:24:1) was added, and the tubes were vortexed briefly. Phases were separated by centrifugation at $12,000 \mathrm{rpm}$ for $10 \mathrm{~min}$, and the aqueous top phase was transferred to a new tube. The phenol:chloroform: isoamyl alcohol treatment and centrifugation steps were repeated. Then, $700 \mu \mathrm{l}$ of chloroform:isoamyl alcohol (24:1) was added to the supernatant, which was vortexed and then spun at 12,000 rpm for $5 \mathrm{~min}$. The aqueous phase was collected, and $20 \mu \mathrm{l}$ of $3 \mathrm{M}$ sodium acetate and 0.5 volume of isopropyl alcohol were added. DNA was precipitated by inverting the tubes gently several times and centrifuging for 10 min at $13,000 \mathrm{rpm}$ at $4^{\circ} \mathrm{C}$. The supernatant was decanted off and pellets were resuspended in $100 \mu$ of Tris-EDTA (TE) buffer (10 $\mathrm{mM}$ Tris-HCI and 0.5 M EDTA), $\mathrm{pH} 8$, and stored at $-20^{\circ} \mathrm{C}$.

Sampling of naturally infected cankers. Grapevine wood samples were collected from three Eutypa dieback-affected

TABLE 1. (continued from preceding page)

\begin{tabular}{|c|c|c|c|c|c|c|}
\hline \multirow[b]{2}{*}{ Fungus, isolate ID } & \multirow[b]{2}{*}{ Host } & \multirow[b]{2}{*}{ Origin } & \multirow[b]{2}{*}{ GenBank number ${ }^{\mathrm{b}}$} & \multicolumn{3}{|c|}{ PCR result ${ }^{\mathrm{a}}$} \\
\hline & & & & ITS1F, ITS4 & EL1, EL4 & EV1, EV4 \\
\hline
\end{tabular}

Eutypella vitis

(continued from preceding page)

E. vitis MI-4-51-3

E. vitis MI-4-51-4

E. vitis MI-4-51-5

E. vitis MI-4-51-7

E. vitis MI-9-24-3

E. vitis MI-9-24-5

Eutypa sparsa $3802-3 \mathrm{a}^{\mathrm{c}}$

E. laevata DF Ass $100^{\mathrm{c}}$

E. tetragona $190802-3^{c}$

E. maura $020202-8^{c}$

E. lejoplaca 020202-3c

E. leptoplaca D-Ca-300

E. leptoplaca D-Neg-100'

Diatrype sp. D-Bey-100'

Diatrype stigma ATCC 64170

Diatrypella sp. D-Ch-500'

Botryosphaeria rhodina $1014^{\mathrm{c}}$

Phaeoacremonium aleophilum A15

Phaeomoniella chlamydospora A18

Acremonium strictum MI- ${ }^{\mathrm{c}}$

Aureobasidium pullulans $\mathrm{MI}-1^{\mathrm{c}}$

Chaetomella sp. MI-1

Chaetomella sp. MI-2

Cryptovalsa ampelina $\mathrm{A} 002^{c}$

Diaporthe sp. MI-1

Fusarium oxysporum MI-1

F. oxysporum $\mathrm{PA} 1^{\mathrm{e}}$

F. oxysporum $\mathrm{PA} 3^{\mathrm{e}}$

Guignardia sp. MI-1

Pestalotiopsis sp. MI-1

Phomopsis sp. MI-1

Phomopsis sp. MI-2

Phomopsis sp. $\mathrm{OH} 48^{\mathrm{f}}$

Phomopsis vaccinii MI-1

$P$. viticola $\mathrm{MI}-3 \mathrm{~A}$

$P$. viticola $\mathrm{OH} 26^{\mathrm{f}}$

Phyllosticta sp. MI-1

Sordaria sp. MI-1

Trichoderma sp. TRSP02-040-1

Trichoderma sp. TRSP02-040-2
V. labrusca 'Concord'

V. labrusca 'Concord'

V. labrusca 'Concord'

V. labrusca 'Concord'

V. labrusca 'Concord'

V. labrusca 'Concord'

Populus sp.

Salix sp.

Laburnum alpinum

Acer sp.

Acer pseudoplatanus

A. macrophyllum

A. negundo

Umbellularia californica

Rhamnus frangula

Quercus sp.

Vitis vinifera

$V$. vinifera

$V$. vinifera

Vaccinium macrocarpon

Vitis sp.

Fragaria $\times$ ananassa

V. macrocarpon

Vitis vinifera

Vaccinium macrocarpon

Fragaria $\times$ ananassa

Vitis sp.

Vitis sp.

Vaccinium macrocarpon

V. macrocarpon

V. macrocarpon

V. macrocarpon

Vitis sp.

Vaccinium macrocarpon

Vitis sp.

Vitis sp.

Vaccinium macrocarpon

Fragaria $\times$ ananassa

$V$. macrocarpon

V. macrocarpon

Lawton, MI
Lawton, MI
Lawton, MI
Lawton, MI
Lawton, MI
Lawton, MI
Switzerland
France
Switzerland
Switzerland
Switzerland
California
California
California
Sweden
California
California
California
California
Michigan
Michigan
Michigan
Michigan
Australia
Michigan
Michigan
Pennsylvania
Pennsylvania
Michigan
Michigan
Michigan
Michigan
Ohio
Michigan
Michigan
Ohio
Michigan
Michigan
Michigan
Michigan

AY462573

AY462574

AY462575

AY462576

AY462577

AY462578

AY684219

AY684223 $3^{\mathrm{d}}$

AY684222

...

AY684229d

AY684235

AY684241

AY $684240^{d}$

...

$\ldots$

$\ldots$

$\cdots$

$\ldots$

$\cdots$

$\cdots$

$\ldots$

...

AY462579

AY462580

...

$\cdots$

$\ldots$

$\ldots$

...

..

...

..

. 
Concord vineyards in southwest Michigan (Lawton, Marcellus, and Berrien Springs). Sawdust was collected by drilling cankered areas showing stromata on selected vines with a cordless drill (Black and Decker, Towson, MD) with a 3.175-mm drill bit. Precautions were taken to prevent cross contamination of samples: The drill bit was washed in $70 \%$ EtOH and flame-sterilized between extractions. Laboratory film (Pechiney Plastic Packaging, Chicago) was wrapped tightly around the chuck at the base of the bit to prevent sawdust from entering the drill and replaced between each extraction. Canker tissue was drilled to a depth of $\approx 5 \mathrm{~mm}$, yielding 25 to $50 \mathrm{mg}$ of sawdust, which proved adequate for DNA extraction and the subsequent PCR protocol. Fourteen wood samples were collected by drilling directly into stromata on suspected Eutypa dieback cankers on symptomatic vines, and a negative control sample was taken from an apparently healthy vine. For confirmation, stromata also were brought back to the laboratory and single-ascospore isolations were performed as previously described. Twelve cankers from symptomatic vines that did not have visible stromata were sampled by drilling, once from the center and once from the margin of each canker. For conformation, wood chips were collected next to the sampling sites and cultured on PDA amended with ampicillin $\left(50 \mathrm{mg} \mathrm{liter}^{-1}\right)$.

Fungal DNA extraction from woody tissues. The sawdust samples were placed in $1.5-\mathrm{ml}$ microcentrifuge tubes, and DNA extractions were carried out as described by Hamelin et al. $(27,28)$ with minor modifications. Wood samples were soaked in $300 \mu \mathrm{l}$ of cetyltrimethylammonium bromide (CTAB) extraction buffer ( $2 \%$ cetyltrimethylammonium, $1.4 \mathrm{M} \mathrm{NaCI}, 1 \%$ polyethylene glycol 8000, 20 mM EDTA, 1\% 2-mercaptoethanol, $100 \mathrm{mM}$ Tris-HCI, $\mathrm{pH}$ 9.5) and ground with an acid-treated, sterilized mortar and pestle. Extracts were incubated at $65^{\circ} \mathrm{C}$ for $2 \mathrm{~h}$. Following the addition of $300 \mu \mathrm{l}$ of phenol:chloroform:isoamyl alcohol (25:24:1), extracts were centrifuged at $10,000 \mathrm{rpm}$ for $5 \mathrm{~min}$. The aqueous phase was transferred to a new tube, precipitated with an equal volume of cold isopropanol, and centrifuged at $10,000 \mathrm{rpm}$ for $10 \mathrm{~min}$. Pellets were washed with cold $70 \%$ ethanol, air dried for $\approx 1 \mathrm{~h}$, and resuspended in $50 \mu \mathrm{l}$ of TE buffer. The samples were heated briefly at $65^{\circ} \mathrm{C}$ to ensure complete suspension.

PCR amplification of internal transcribed spacers. DNA extracted from mycelium was diluted $10^{2}$ and $10^{3}$ times in sterile water, and the ITS regions and 5.8S gene of the nuclear ribosomal RNA operon (ITSI-5.8S-ITSII) were amplified with the primers ITS1F (fungus specific: 5'-CTTGGTCATTTAGAGGAAGTAA$3^{\prime}$ ) and ITS4 (universal: 5'-TCCTCCGCTTATTGATATGC-3') $(20,57)$. PCR reactions were carried out in $25 \mu \mathrm{l}$ of total volume consisting of $12.5 \mu \mathrm{l}$ of DNA dilution (template) and $12.5 \mu \mathrm{l}$ of $\mathrm{PCR}$ reaction mixture. The reaction mixture contained PCR buffer (20 mM ammonium sulfate; $2.0 \mathrm{mM} \mathrm{MgCI}_{2} ; 50 \mathrm{mM}$ Tris-HCI, pH 9.0) (Epicentre Technologies, Madison, WI); $0.2 \mathrm{mM}$ each dATP, dTTP, dGTP, and dCTP; $0.5 \mu \mathrm{M}$ each ITS1F and ITS4 primers; and 0.5 unit of Taq DNA polymerase. The reactions were carried out in a DNA thermal cycler (Model 9600; Perkin-Elmer Cetus, Norwalk, CT). The amplification protocol included an initial denaturation at $95^{\circ} \mathrm{C}$ for $3 \mathrm{~min}$ followed by 30 cycles at $94^{\circ} \mathrm{C}$ for $1 \mathrm{~min}, 50^{\circ} \mathrm{C}$ for $1 \mathrm{~min}$, and $72^{\circ} \mathrm{C}$ for $1 \mathrm{~min}$. The reaction was completed by a $7-$ min extension at $72^{\circ} \mathrm{C}$. PCR products were separated on $1.5 \%$ agarose (Gibco BRL, Grand Island, NY) in $1 \%$ Tris-acetate-EDTA buffer (100 mM Tris, $12.5 \mathrm{mM}$ sodium acetate, and $1 \mathrm{mM}$ EDTA, pH: 8.0) by gel electrophoresis. A 1-kb-plus DNA ladder (Gibco BRL) was included in each gel as a DNA size standard. The gels were stained with ethidium bromide, visualized by UV fluorescence, and photographed using an AlphaImager imaging system (Alpha Innotech Corporation, San Leandro, CA).

Sequencing and primer design. ITS1F- and ITS4-amplified PCR products of 25 Eutypa lata and 15 Eutypella vitis isolates were purified using Millipore Ultrafree-MC 30,000 NMWL purification filters (Millipore Corporation, Bedford, MA). PCR products (100 to $150 \mu \mathrm{l})$ were washed with water four times by spinning at $4,000 \mathrm{rpm}$ at $4^{\circ} \mathrm{C}$. Purified PCR products were run on $3 \%$ high-melt agarose gels at $100 \mathrm{~V}$ for quantification before sequencing. PCR products of ITS and 5.8S rRNA were sequenced by using ITS1F and ITS4 primers in an Applied Biosystems 370A Sequencer (Applied Biosystems, Foster City, CA) with the Taq DyeDeoxy Terminator System. Sequencing was carried out by the Genomics Technology Support Facility at Michigan State University. Primers ITS5, ITS3, and ITS2 also were used for sequencing to ensure fidelity of the sequences (57). ITS sequences were edited, aligned, and corrected using the programs EditSeq, MegAlign, and SeqMan in the DNASTAR software package (DNASTAR, Inc., Madison, WI). Each sequence was compared with the sequences in GenBank (National Center for Biotechnology Information, Bethesda, MD) using the similarity search program BLAST $(1,2)$. In addition to the sequences of Eutypa lata and Eutypella vitis, available sequences of other Diatrypaceous fungi (Diatrype sp. AY684241, Diatrypella sp. AY684240, Eutypa astroidea AJ302458, E. consobrina AJ302447, E. crustata AJ302448, E. flavovirens AJ302457, E. laevata AJ302449, E. lejoplaca AY684238, E. leptoplaca AJ302453, E. maura AJ302454, E. petrakii var. petrakii AJ302456, E. sparsa AY684220, E. tetragona AY684223, Eutypella scoparia AF373064, E. cerviculata AJ302461, E. quaternata AJ302469, E. cerviculata AJ302468, E. alsophila AJ302467, E. vitis AJ302466, E. scoparia AJ302465, E. prunastri AJ302464, E. leprosa AJ302463, E. kochiana AJ302462, and E. caricae AJ302460) were included in the alignment for primer selection. Primers were evaluated for annealing temperature, GC content, and secondary structure with the Primer Select program (DNASTAR). Primers were synthesized at the Macromolecular Structure and Sequencing Facility (Department of Biochemistry, Michigan State University) using a 3948 Oligonucleotide Synthesizer (Applied Biosystems).

Primer specificity. Specificity of specific primer pairs EL1 and EL4 for Eutypa lata and EV1 and EV4 for Eutypella vitis was assessed by PCR using purified DNA from isolates of Eutypa lata and Eutypella vitis and other pathogenic, saprophytic, and endophytic fungi (Table 1). Aside from the Diatrypaceous fungi, the other fungi were chosen because they are common in the environment or represent genera of fungi also found on grapevines (Table 1). The primer pair ITS1F and ITS4 was used to verify that DNA extracts were suitable for amplification. PCR amplifications using the ITS and species-specific primers were carried out as previously described.

Nested multiplex PCR on naturally infected vines. To detect Eutypa lata and Eutypella vitis in culture and in planta, a nested multiplex PCR protocol was developed. This method is based on a two-step approach. In the first round of amplification, universal primers (ITS1F and ITS4) are used to enrich the amount of fungal DNA present in the sample. Products from the first round then are used as the template for the second round, with all of the speciesspecific primers (EL1, EL4, EV1, and EV4) included in a multiplex reaction. DNA isolated from woody tissue was diluted $10^{2}$ times for PCR reactions. The first round of PCR reactions was carried out in $25 \mu \mathrm{l}$ of total volume consisting of $1 \mu \mathrm{l}$ of DNA dilution (template) and $24 \mu \mathrm{l}$ of PCR reaction mixture as described above, with $10 \mu \mathrm{M}$ each of the primers ITS1F and ITS4. The amplification protocol for the first step included an initial denaturation at $94^{\circ} \mathrm{C}$ for $2 \mathrm{~min}$, followed by 30 cycles at $94^{\circ} \mathrm{C}$ for $1 \mathrm{~min}, 50^{\circ} \mathrm{C}$ for $30 \mathrm{~s}$, and $72^{\circ} \mathrm{C}$ for $1 \mathrm{~min}$. The reaction was completed by a 5 -min extension at $720^{\circ} \mathrm{C}$. The first round of PCR ( 1 $\mu \mathrm{l})$ was used as the template for the second round. PCR reactions were carried out in $25 \mu \mathrm{l}$ of total volume consisting of the PCR reaction mixture as described above with $5 \mu \mathrm{M}$ each of the primers EL1, EL4, EV1, and EV4. The amplification protocol for the second step included an initial denaturation at $94^{\circ} \mathrm{C}$ for $2 \mathrm{~min}$, followed by 35 cycles at $94^{\circ} \mathrm{C}$ for $1 \mathrm{~min}, 62^{\circ} \mathrm{C}$ for $30 \mathrm{~s}$, and $72^{\circ} \mathrm{C}$ for $1 \mathrm{~min}$. The reaction was completed by a 5 -min ex- 
tension at $72^{\circ} \mathrm{C}$. The positive controls consisted of fungal DNA from a pure culture of the respective fungus with a negative control consisting of DNA extracted from wood of apparently healthy vines. Positive and negative controls were used in all PCR reactions. Gel electrophoresis, ethidium bromide staining, visualization, and photography of the PCR products were conducted as described above with one exception: second-step PCR products were separated on $2 \%$ agarose gels. To ensure the validity of the PCR results, all 300- and 350-bp amplicons (a total of 39 amplicons) for Eutypa lata and Eutypella vitis, respectively, were sequenced by the Genomics Technology Support Facility at Michigan State University using the forward species-specific primers EL1 and EV1.

Nested multiplex PCR on artificially inoculated vines. Two isolates of E. vitis from Michigan (EV70 and EV339), and two isolates of Eutypa lata, one from Michigan (EL130) and one from California, (E30) were used to inoculate healthy, dormant, 1-year- old V. labrusca Concord canes with two intact nodes. Isolates were cultured on PDA for 5 days prior to inoculation. Four canes were inoculated for each isolate. Prior to inoculation, a cordless drill was used to make a shallow, 3-mm-diameter hole $\approx 2 \mathrm{~cm}$ below the upper node of each cane. A plug of agar with mycelium was inserted into the hole and sealed with parafilm. The bottom node was cut, wetted, and dipped in Hormodin 2 (E. C. Geiger Inc., Harleysville, PA ), and the canes were planted in a mixture of two parts sand and one part Baccto Potting Soil (Michigan Peat Co., Houston) in $20-\mathrm{cm}$ pots. The negative control consisted of canes inoculated with a sterile plug of PDA. Following 6 months of growth in a greenhouse, tissue was removed from each cane $\approx 5 \mathrm{~mm}$ below the edge of the site of inoculation. DNA was extracted and nested multiplex PCR was performed as described previously. Tissue from the same site also was surface sterilized and plated on ampicillin-amended PDA $\left(50 \mathrm{mg} \mathrm{liter}^{-1}\right)$. The presence or absence of E. lata or Eutypella vitis was determined by

\begin{tabular}{|c|c|}
\hline & ITS1 \\
\hline & $\begin{array}{ll}101 & 170\end{array}$ \\
\hline EL-MI-7-1 & GCTACCСTGTAGCCCGCTGCAGGCCTACCCGCCGGTGGACGCCT-AAACTCTTGTTTTTCAGTGAT-TA \\
\hline EL-MI-3B-1 & GСTACCСTGTAGCCСGCTGCAGGCCTACCCGCCGGTGGACGCCT-AAACTCTTGTTTTTTAGTGAT-TA \\
\hline EL-MI-3-25-1 & GСTACCСTGTAGCCCGCTGCAGGCCTACCCGCCGGTGGACGCCT-АAACTCTTGTTTTTCAGTGAT-TA \\
\hline EL-MI-8-1 & GCTACCCTGTAGCCCGCTGCAGGCCTACCCGCCGGTGGACGCCT-AAACTCTTGTTTTTCAGTGAT-TA \\
\hline EL-CA30 & GCTACCCTGTAGCCCGCTGCAGGCCTACCCGCCGGTGGACACTT-AAACTCTTGTTTTTTAGTGAT-TA \\
\hline EL-PA2 & GCTACCCTGTAGCCCGCTGCAGGCCTACCCGCCGGTGGACGCCT-AAACTCTTGTTTTTTAGTGAT-TA \\
\hline E. leptoplaca & GCTACGCTGTAGCCCGCTGCAGGCCAACCCGCCGGTGGACTGTT-AAACTCTTGTTATAGTGGAAC-T- \\
\hline $\mathrm{EV}-\mathrm{MI}-4-51-1$ & GGTACCCTGTA-------AGGACTACTCGTCGACGGAC-CATTAAACTCT-GTTTTTCTATGAAACT \\
\hline EV-MI-2-1 & GTTACCCTGTA-"----AGGACTACTCGTCGACGGAC-CATTAAACTCT-GTTTTTCTATGAAACT \\
\hline EV-MI $-9-24-3$ & GCTACCCTGTA------AGGACTACTCGTCGACGGAC-CATTAAACTCT-GTTTTTCTATGAAACT \\
\hline EV-MI-3A-1 & GCTACCCTGTA-------AGGACTACTCGTCGACGGAC-CATTAAACTCT-GTTTTTCTATGAAACT \\
\hline EV-I302466 & GCTACCCTGTA------AGGAATACTCGTCGACGGAC-CATTAAACTCT-GTTTTTCTATGAAACT \\
\hline Diatrype sp. & GCTACCCTGTAGCCCGCTGCTGGCCGACCCGCCGGTGGACAGTA-AAACTCTTGTTTTTTAGTGAT-TA \\
\hline
\end{tabular}

ITS2

381

EL-MI - 7-1

EL-MI - 3B-1

EL-MI - 3-25-1

EL-MI $-8-1$

EL-CA30

EL-PA2

E. leptoplaca

EV-MI-4-51-1

EV-MI $-2-1$

EV-MI $-9-24-3$

EV-MI $-3 \mathrm{~A}-1$

EV-I 302466

Diatrype sp.

TTGGGAGCTT--ATCTTC----GGAT---AACTCCCCAAAAGCATCGGCGGAGTCGCGGTGGCCCCAAG TTGGGAGCCT--ATCTTC----GGAT---AACTCCCCAAAAGCATCGGCGGAGTCGCGGTGGCCCCAAG TTGGGAGCTT--ATCTTC----GGAT---AACTCCCCAAAAGCATCGGCGGAGTCGCGGTGGCCCCAAG TTGGGAGCTT--ATCTTC----GGAT---AACTCCCCAAAAGCATCGGCGGAGTCGCGGTGGCCCCAAG TTGGGAGCCT--ATCTCC----GGAT---AGCTCCTCAAAAGCATTGGCGGAGTCGCGGTGACCCCAAG TTGGGAGCCT--ATCTTC----GGAT---AACTCCCCAAAAGCATCGGCGGAGTCGCGGTGGCCCCAAG TTGGGAGTTTAC-----CTGCGGGT---AATTCCTGAAAAGCATCGGCGGAGTCGTGTTGGCCCCAAG TTGGGAGCTTAC-CCTGCAGTTGCGGATAACTCCTCAAATATATTGGCGGAGTCGCGGAGACCCTAAG TTGGGAGCTTAC-CCTGCAGTTGCGGGATAACTCCTCAAATATATTGGCGGAGTCGCGGAGACCCTAAG TTGGGAGCTTAC-CCTGCAGTTGCGGGATAACTCCTCAAATATATTGGCGGAGTCGCGGAGACCCTAAG TTGGGAGCTTAC-CCTGCAGTTGCGGGATAACTCCTCAAATATATTGGCGGAGTCGCGGAGACCCTAAG TTGGGAGCTTAC-CCTGCAGTTGCGGGATAACTCCTCAAATATATTGGCGGAGTCGCGGAGACCCTAAG TTGGGAGCCTGC-CCCCCCAGGGGA--GCAGCTCCTCAAAGCTATTGGCGGAGTCGTATTGGCCCTAAG Diatrypella sp. TTGGGAGCCTGCACCCCCCCGGGGGCTGCAGCTCCTCAAAGCTATTGGCGGAGTCGTATTGGCCCTAAG

ITS2

441

510

EL-MI $-7-1$

EL-MI - 3B-1

EL-MI-3-25-1

EL-MI - 8-1

EL-CA 30

EL-PA2

E. 1eptoplaca

EV-MI - 4-51-1

EV-MI - 2-1

EV-MI-9-24-3

EV-MI - 3A-1

EV-I302466

Diatrype sp.

CGTAGTAATTTTT-CCTCGCTT--AGGTGTGCTACGGTCGACGTCCTGCCGTAAAACCCCCTATTTTCT CGTAGTAATTTTT-CCTCGCTT--AGGTGTGCTACGGTCGACGTCCTGCCGTAAAACCCCCTATTTTCT CGTAGTAATTTTT-CCTCGCTT--AGGTGTGCTACGGTCGACGTCCTGCCGTAAAACCCCСTATTTTCT CGTAGTAATTTTT-CCTCGCTT--AGGTGTGCTACGGTCGACGTCCTGCCGTAAAACCCCCTATTTTCT CGTAGTAATTCTT-CTCGCTTT--AGGTGTGTCACGGCTGACGTCTTGCCGTTAAACCCCCAATTTTTT CGTAGTAATTTTT-CCTCGCTT--AGGTGTGCCACGGCCGACGTCCTGCCGTAAAACCCCCTATTTTCT CGTAGTAATTTTT--CTCGCTTCAGGTGGTTCCAGCGCTGGCGTCCAGCCGCTAAACCCCCTATTCTTT CGTAGTAATTCTT--CTCGCTT-TAGTAGTGTTAACGCTGGCATCTGGCCACTAAACCCCTAATTTTTA CGTAGTAATTCTT--CTCGCTT-TAGTAGTGTCAACGCTGGCATCTGGCCACTAAACCCCTAATTTTTA CGTAGTAATTCTT--CTCGCTT-TAGTAGTGTTAACGCTGGCATCTGGCCACTAAACCCCTAATTTTTA CGTAGTAATTCTT--CTCGCTT-TAGTAGTGTCAACGCTGGCATCTGGCCACTAAACCCCTAATTTTTA CGTAGTAATTCTT--CTCGCTT-TAGTAGTGTTAACGCTGGCATCTGGCCACTAAACCCCTAATTTTTA CGTAGTAATTTTTTCCTCGCTTCTAGTGGTTCCAGTGCTGGCGTCCAGCCGTAAAACCCCTAATTTTCT Diatrypella sp. CGTAGTAATTTTTTCCTCGCTTCTAGTGGTTCCAGTGCTGGCGTCCAGCCGTAAAACCCCTAATTTTCT

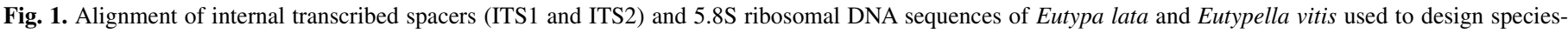

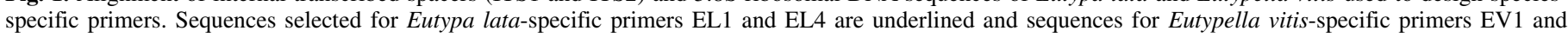

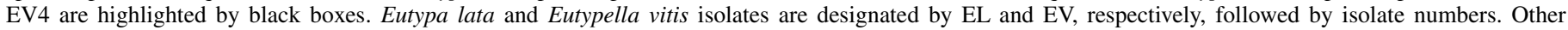

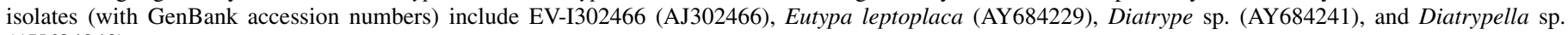
(AY684240). 
culture morphology characteristics after 1 week of incubation. Gel electrophoresis, ethidium bromide staining, visualization, and photography of the PCR products were conducted as described above.

Sensitivity of standard compared with nested multiplex PCR. Extracted DNA from pure cultures of Eutypa lata and Eutypella vitis was used to make 10-fold serial dilutions (3 $\mathrm{ng}$ to $30 \mathrm{ag}$ ) to determine the sensitivity of the nested multiplex PCR in comparison to standard PCR. Standard PCR and nested multiplex PCR were conducted as described above on each dilution series and with both series combined in the same reaction. Reactions were replicated three times with a water control included in each reaction. Gel electrophoresis, ethidium bromide staining, visualization, and photography of the PCR products were conducted as described above.

\section{RESULTS}

Isolate characteristics. More than 100 single-ascospore isolates each of Eutypa lata and Eutypella vitis were cultured from wood samples collected from three different vineyards in Michigan. Both fungi were found in each vineyard, sometimes on the same vine. It was difficult to tell the stromata of the two fungi apart, although Eutypa lata perithecia appeared to be more deeply embedded in the wood than Eutypella vitis perithecia. In general, E. vitis cultures grew somewhat faster than Eutypa lata cultures and tended to have fluffy, aerial mycelium early in development as well as black streaking or blotches as they aged. However, culture appearance was variable and some E. lata cultures also developed dark blotches as they aged, making it difficult to distinguish the species based on culture characteristics.

Sequences of ITS region and primer design. The length of the ITS regions of E. lata and Eutypella vitis sequenced in this study was $\approx 503$ and 492 bp, respectively. A Blast search was performed for each sequence to confirm its similarity to existing sequences of Eutypa lata and Eutypella vitis. The sequences were submitted to GenBank and an accession number was obtained for each sequence (Table 1). Upon alignment, there was variability in the ITS sequences of Eutypa lata isolates from different locations. Although isolates from Michigan shared a sequence homology of 99 to $100 \%$, they had 98 and $95 \%$ sequence similarity to the isolates from Pennsylvania and California, respectively. All the sequences of Eutypella vitis, including the existing sequences in GenBank, were 99 to $100 \%$ homologous. However, ITS sequences of Eutypa lata were only $88 \%$ similar to sequences of Eutypella vitis. Species-specific primers were designed from the ITS sequences that varied between species in the same genus but were conserved among isolates of the same species (Fig. 1). The ITS2 region was more variable than the ITS1 region among the isolates of Eutypa lata. Primer pairs EL1-EL4 and EV1-EV4 (Fig. 2) were developed from the most conserved region within each species that was most variable between species for specific amplification of E. lata and Eutypella vitis, respectively (Table 2).

PCR amplification for primer specificity. The specific primer pairs designed for Eutypa lata and Eutypella vitis were tested against isolates of Eutypa lata, Eutypella vitis, and other fungi (Table 1). Primer pairs EL1-EL4 and EV1-EV4 specifically amplified DNA of only their respective targets, Eutypa lata and Eutypella vitis, in all reactions (Table 1). The primers did not cross-react with DNA of any other fungal species tested. Primer pair EL1-EL4 produced a single, expected PCR amplicon of $345 \mathrm{bp}$, whereas the pair EV1-EV4 yielded a single PCR product of $299 \mathrm{bp}$.

Nested multiplex PCR on naturally infected vines. The species-specific primers were tested on naturally infected vines for their ability to detect Eutypa lata or Eutypella vitis. The first round of nested multiplex PCR of samples from cankers with visible stromata (Fig. 3A) resulted in visible products of the ITS amplicon $(\approx 600 \mathrm{bp})$ in 7 of the 14 samples (lanes $3,4,8$, and 11 to 14). The second round of PCR (Fig. 3B) resulted in visible

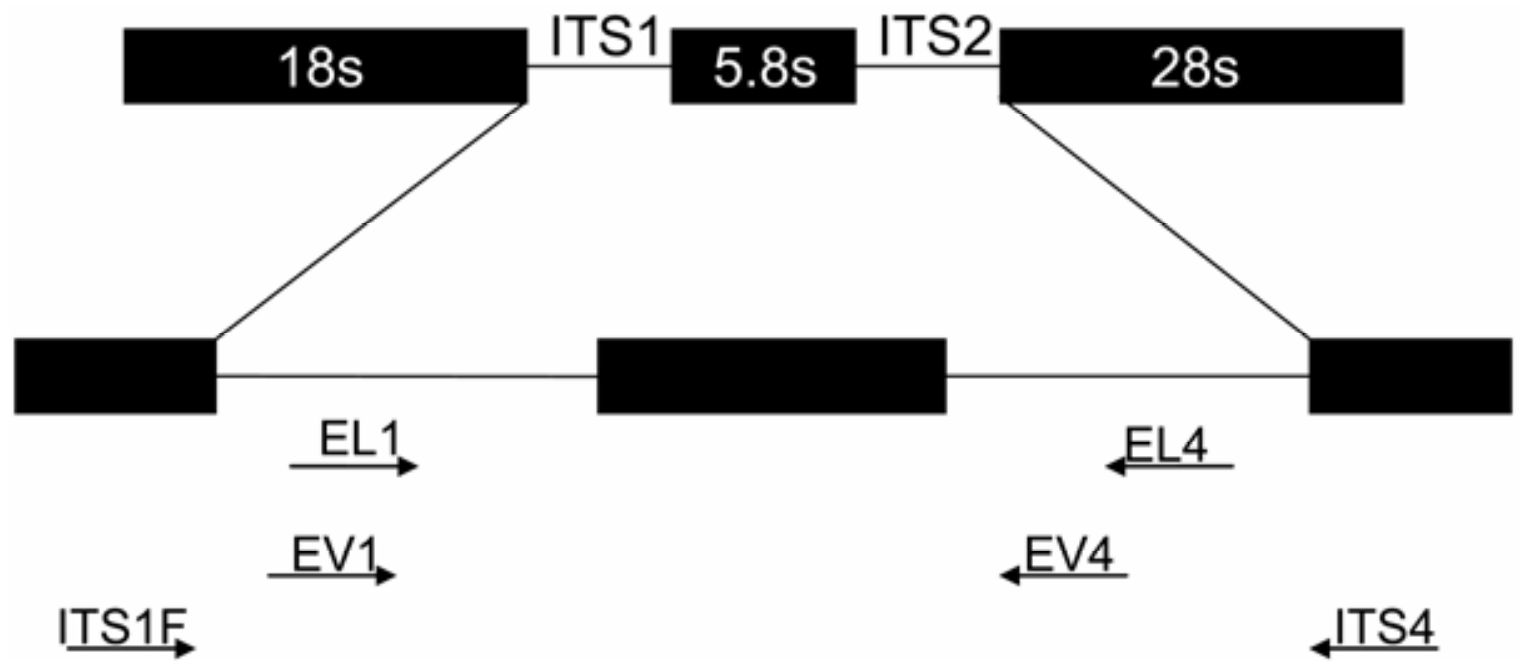

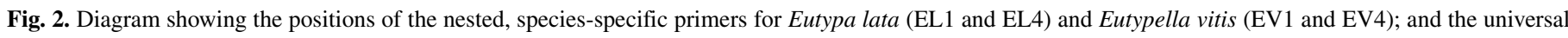

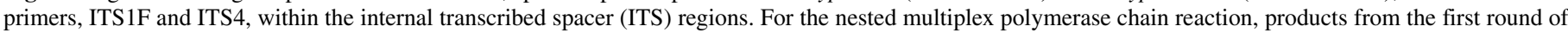

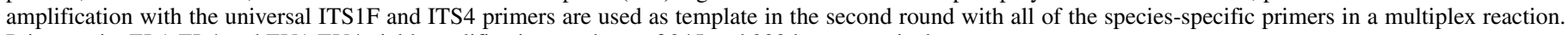
Primer pairs EL1-EL4 and EV1-EV4 yield amplification products of 345 and $299 \mathrm{bp}$, respectively.

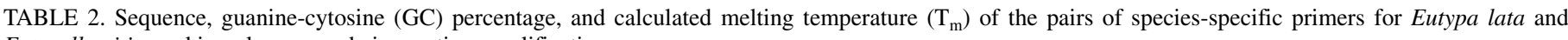
Eutypella vitis used in polymerase chain reaction amplifications

\begin{tabular}{|c|c|c|c|c|}
\hline Species & Primer & Sequence $\left(5^{\prime}-3^{\prime}\right)$ & $\mathrm{GC}(\%)$ & $\mathrm{T}_{\mathrm{m}}$ \\
\hline \multirow[t]{2}{*}{ Eutypa lata } & EL1 & GACGCCTAAACTCTTGTTTTTCAGTGATTA & 37 & 57 \\
\hline & EL4 & AGGACGTCGACCGTAGCACACCTA & 58 & 63 \\
\hline \multirow[t]{2}{*}{ Eutypella vitis } & EV1 & CCTGTAAGGACTACTCGTCGAC & 55 & 57 \\
\hline & EV4 & AGGAGTTATCCCGCAACTGCAG & 55 & 57 \\
\hline
\end{tabular}


products for 13 of the 14 samples: 8 samples (lanes 3 to 6 and 12 to 15$)$ with single bands indicating E. vitis (299 bp) and 5 samples (lanes 7 to 11) with single bands indicating Eutypa lata (345 bp). The lone exception was sample 1 (Fig. 3, lane 2), where the diagnostic markers for E. lata and Eutypella vitis were not amplified. Subsequently, we were not able to culture either fungus from the sample. The absence of the fungi in the sample would explain the negative PCR result. Sequencing of the PCR products (GenBank accession numbers DQ658371 to DQ658383) as well as morphological examination and PCR tests of single-ascospore cultures isolated from stromata next to sampling sites on the vines validated the results of the PCR technique (data not shown).

The presence of visible stromata was not necessary for a positive detection because every canker without visible stromata was positive for the presence of either Eutypa lata, Eutypella vitis, or both (Fig. 4). E. vitis was present in the margin of 4 cankers and was found in a total of 5 of the 12 cankers. Eutypa lata was present in 10 of the 12 cankers. Both fungi were present in three of the cankers, with both fungi in the margin of two and Eutypella vitis in the margin and Eutypa lata in the center of one canker. Sequencing of the amplification products (GenBank accession numbers DQ658384 to DQ658409) confirmed that the identity of the fungi correlated with the size of the amplicon. Of the 24 wood chips cultured, only three yielded pure cultures of $E$. lata or Eutypella vitis. The morphological characteristics of the three isolates agreed with the results obtained from the nested multiplex PCR; one isolate of Eutypa lata (from the center of a canker corresponding to Figure 4A, lane 11) and two isolates of Eutypella vitis (from the margin of cankers corresponding to Figure 4B, lanes 3 and 6). Blast searches were performed using all the sequences obtained from the PCR on the stromata and the PCR on the wood. The 299-bp amplicon sequences had the highest sequence homology with isolates of E. vitis (99 to $100 \%$ homology), and the 345-bp amplicon sequences had the highest sequence homology with isolates of Eutypa lata (93 to 100\% homology). Results of the nested multiplex PCR are summarized in Table 3.

Nested multiplex PCR on artificially inoculated vines. The species-specific primers were tested in a nested multiplex reaction with $V$. labrusca Concord canes that were inoculated with two isolates of Eutypella vitis and two isolates of Eutypa lata. For each inoculated cane, a PCR product was produced from DNA extracted $5 \mathrm{~mm}$ below the site of inoculation and was the correct size for the species used (299 bp for EV70 and EV339 and 345 bp for E30 and EL130) (Fig. 5). Isolation from the wood tissue was less successful with three of four canes yielding EV70, one of four canes yielding EV339, two of four canes yielding EL130, and three of four canes yielding E30.

Sensitivity of standard compared with nested multiplex PCR. Using pure DNA extracted from cultures, nested multiplex PCR was consistently 1,000 times more sensitive than standard PCR, with an amplicon obtained with $<1 \mathrm{fg}$ of pathogen DNA (Fig. 6). In reactions with DNA from both fungi, the 299- and 345-bp products both were present in all reactions with visible products, indicating that there was no competition between primers (Fig. 6)

\section{DISCUSSION}

In this study, we developed molecular tools for detection and identification of E. lata and Eutypella vitis, two fungi that occur on grapevines and are difficult to separate based on culture appearance or morphological characteristics. Although the role of E. vitis in Eutypa dieback development is still unclear, preliminary studies indicate that the fungus is pathogenic to grape (30). Species-specific primers designed from the ITS regions of ribosomal DNA clearly distinguished the two species in PCR assays of DNA extracted from mycelium and stromata on wood. The assay also was able to detect these species in cankers without visible stromata on naturally infected vines, demonstrating its

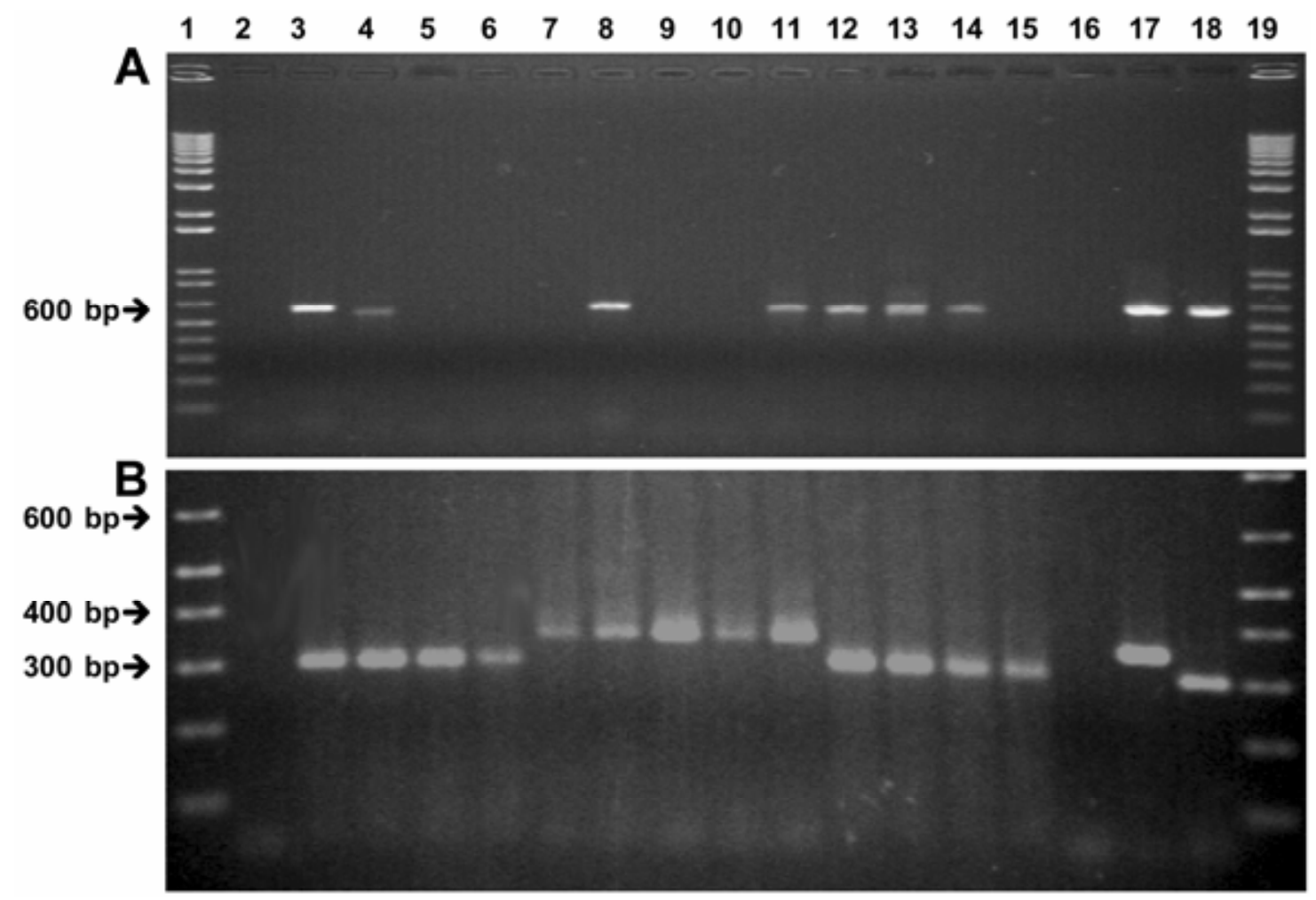

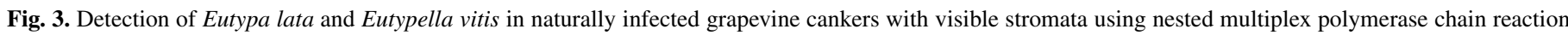

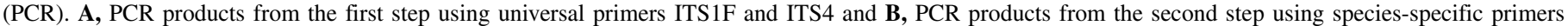

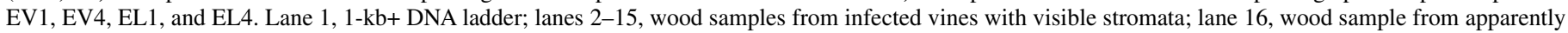
healthy vine (negative control); lane 17, Eutypa lata DNA (positive control); lane 18, Eutypella vitis DNA (positive control); lane 19, 1-kb+ DNA ladder. 
utility as a diagnostic tool. This is the first known report of the presence of $E$. vitis in grapevines with Eutypa dieback symptoms. The presence of E. vitis in the center and margin of several cankers tested also suggests that this fungus is acting as a primary pathogen of grapevines. The nested multiplex PCR approach also was successfully used for the detection of Eutypa lata and Eutypella vitis mycelium in artificially inoculated, potted grapevine plants, indicating the usefulness of this technique in laboratory and greenhouse experiments. This also shows that E. vitis is capable of colonizing healthy grapevines tissue, further lending evidence that E. vitis is pathogenic on grape. Future work will need to be carried out to determine the incidence of E. vitis in Eutypa dieback cankers in Michigan. To date, no adequate survey of the co-colonizers of Eutypa dieback cankers has been conducted in Michigan. The expression of disease symptoms in Concord vines in Michigan is variable between vines and years. It is possible that shoot symptoms are affected by the presence of other fungi like $E$. vitis in cankers. Further research needs to be done before we can fully understand the complexity of Eutypa dieback in the region.

Sequencing of the ITS region of numerous Eutypa lata and Eutypella vitis isolates confirmed that these two fungi are genetically distinct. Analysis of the sequences showed that there is almost no variability in the ITS regions of E. vitis and that the isolates clearly represent one species. In contrast, we observed variability in the ITS regions of isolates of Eutypa lata from three geographic regions in the United States. This was not surprising because genetic variation also was found among isolates from different geographic locations by Peros et al. $(40,41)$. Genetic variation also was common among isolates from the same vineyard and even from the same stroma $(39,40)$. E. lata is considered a randomly mating species with a high degree of genetic diversity, as shown with RFLP and random amplified polymorphic DNA
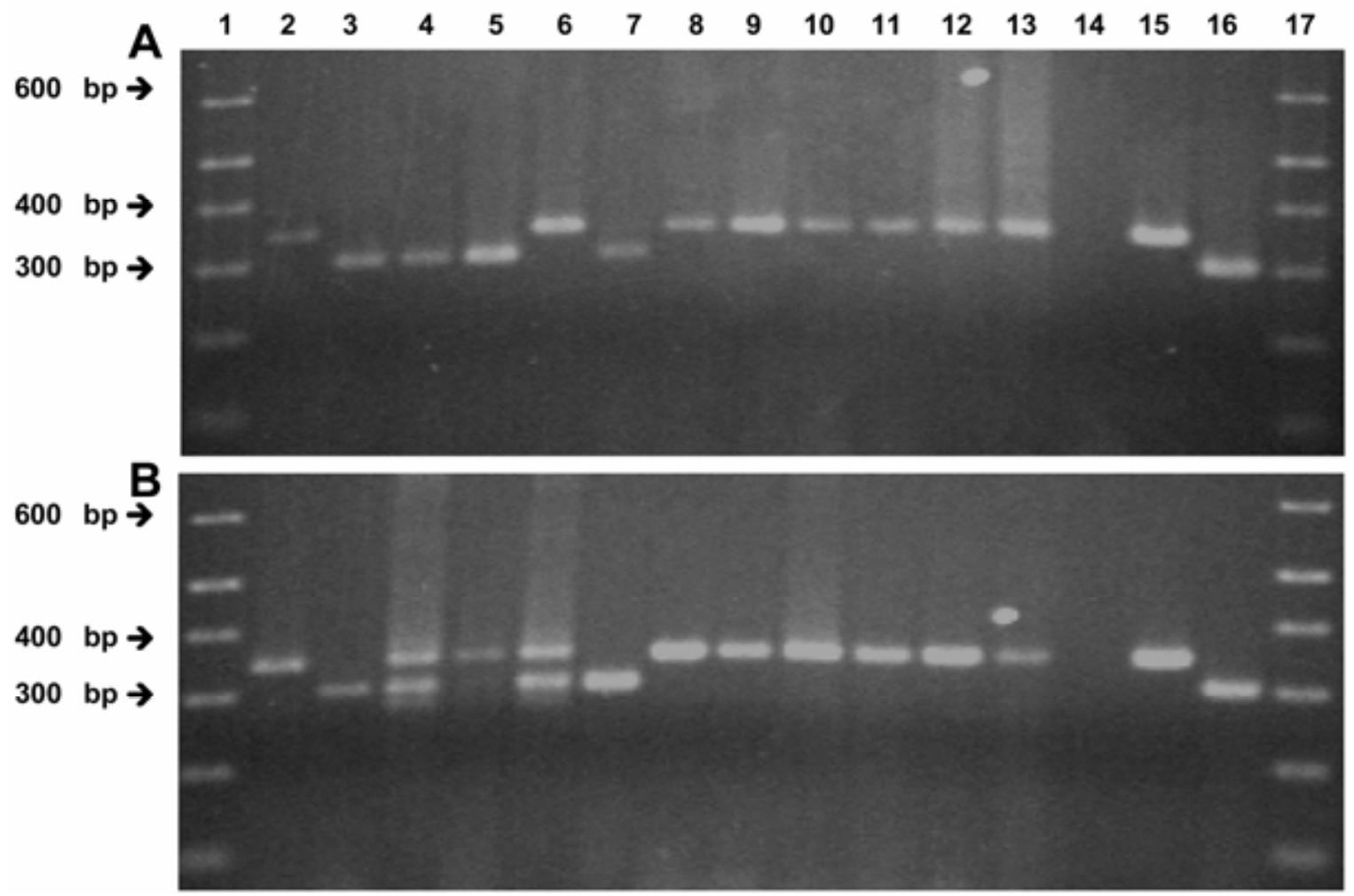

Fig. 4. Detection of Eutypa lata and Eutypella vitis in cankers without visible stromata from naturally infected grapevine using nested multiplex polymerase chain reaction (PCR). A, PCR products from the centers of the cankers and B, PCR products from the margins of the cankers. Lane 1, 1-kb+ DNA ladder; lanes 2-13, wood samples from grapevine cankers without visible stromata; lane 14, wood sample from apparently healthy vine (negative control); lane 15, Eutypa lata DNA (positive control); lane 16, Eutypella vitis DNA (positive control); lane 17, 1-kb+ DNA ladder

TABLE 3. Comparison of traditional diagnostic techniques to the nested multiplex polymerase chain reaction (PCR) for detection of Eutypa lata and Eutypella vitis in naturally infected, symptomatic grapevines (Vitis labrusca 'Concord') in Michigan

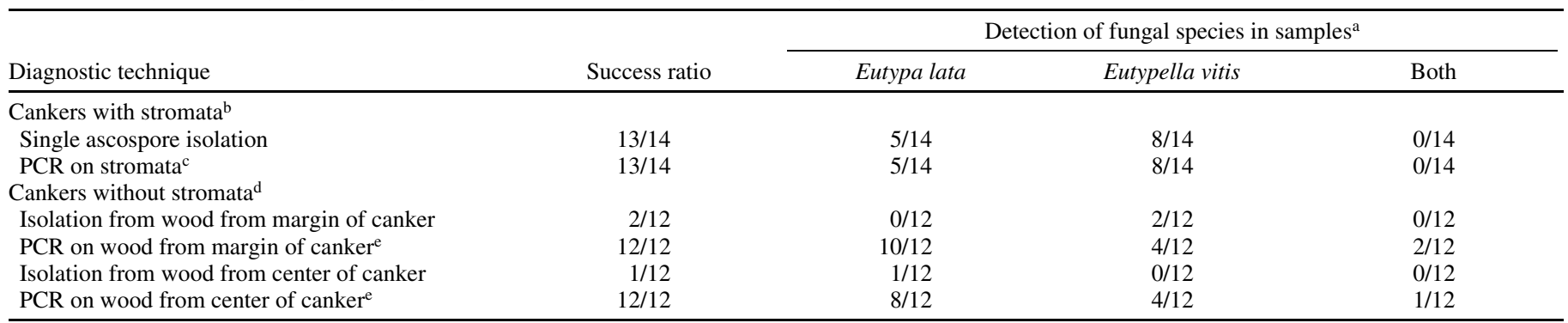

${ }^{a}$ Culture morphology and sequences of PCR products amplified with species-specific primers were used to determine identity.

${ }^{\mathrm{b}}$ Fourteen cankers were sampled, 1 from each of 14 different vines.

c PCR results shown in Figure 3.

d Twelve cankers were sampled, 1 from each of 12 different vines.

e PCR results shown in Figure 4. 
markers, and vegetative compatibility and pathogenicity tests $(39,42)$. DeScenzo et al. (16) suggest that E. lata is not a single species and may be evolving into different species; however, this has since been refuted by a more recent assessment of the species concept of E. lata that supports the merging of E. armeniacae and $E$. lata as a single species (46). More genetic data may help to clarify the status of this species. However, sequences from iso- lates from other parts of the world are needed for phylogenetic analysis of variation in E. lata, because the number of sequences available in GenBank is limited.

Possible primer sites were highly conserved among the Eutypella vitis isolates from different areas, simplifying the design of species-specific primers for this species. However, it was much more difficult to design species-specific primers for

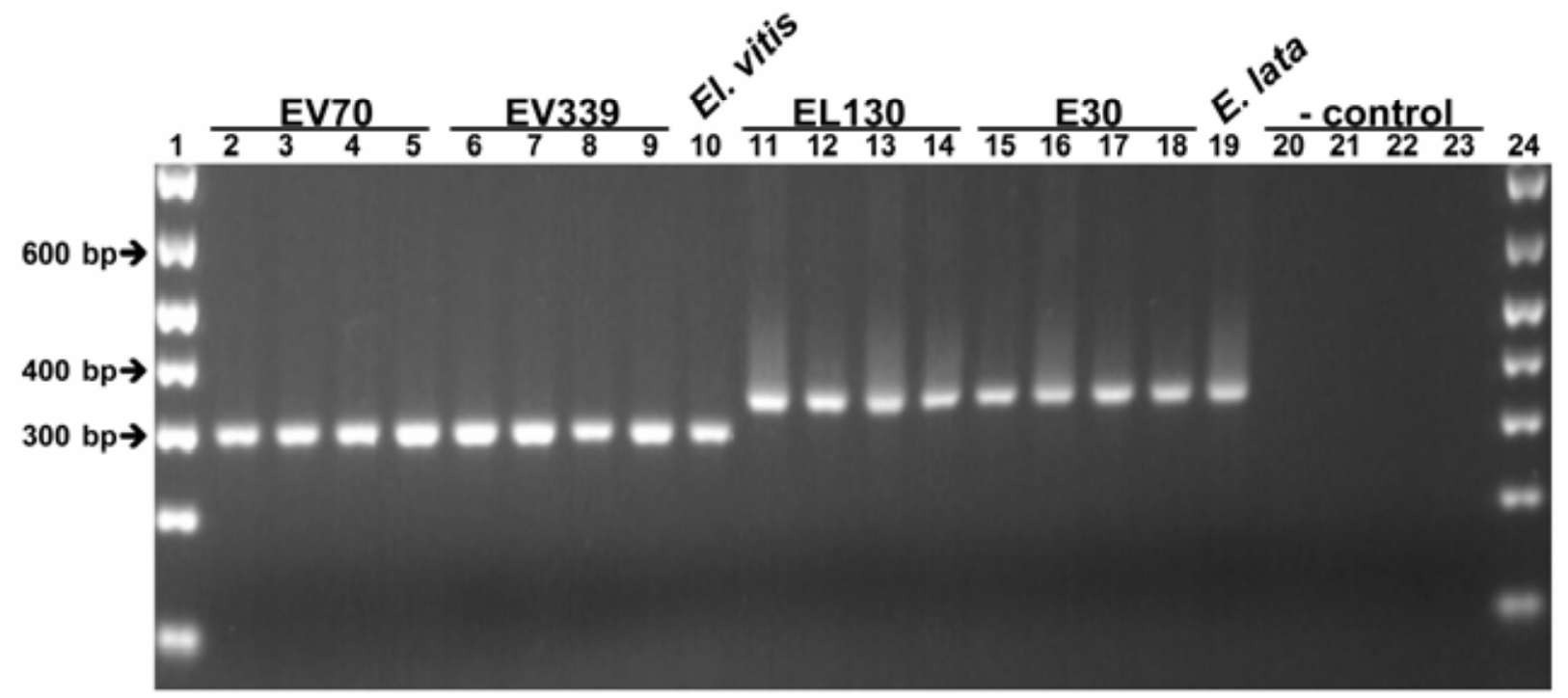

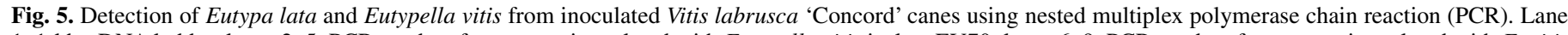

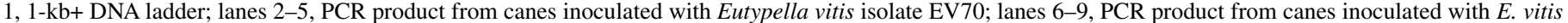

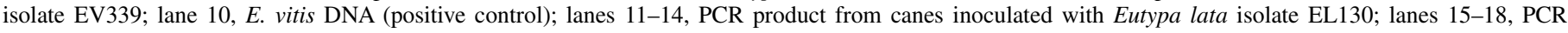

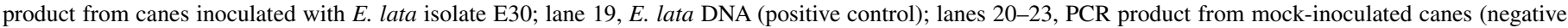
controls); lane 24, 1-kb+ DNA ladder.
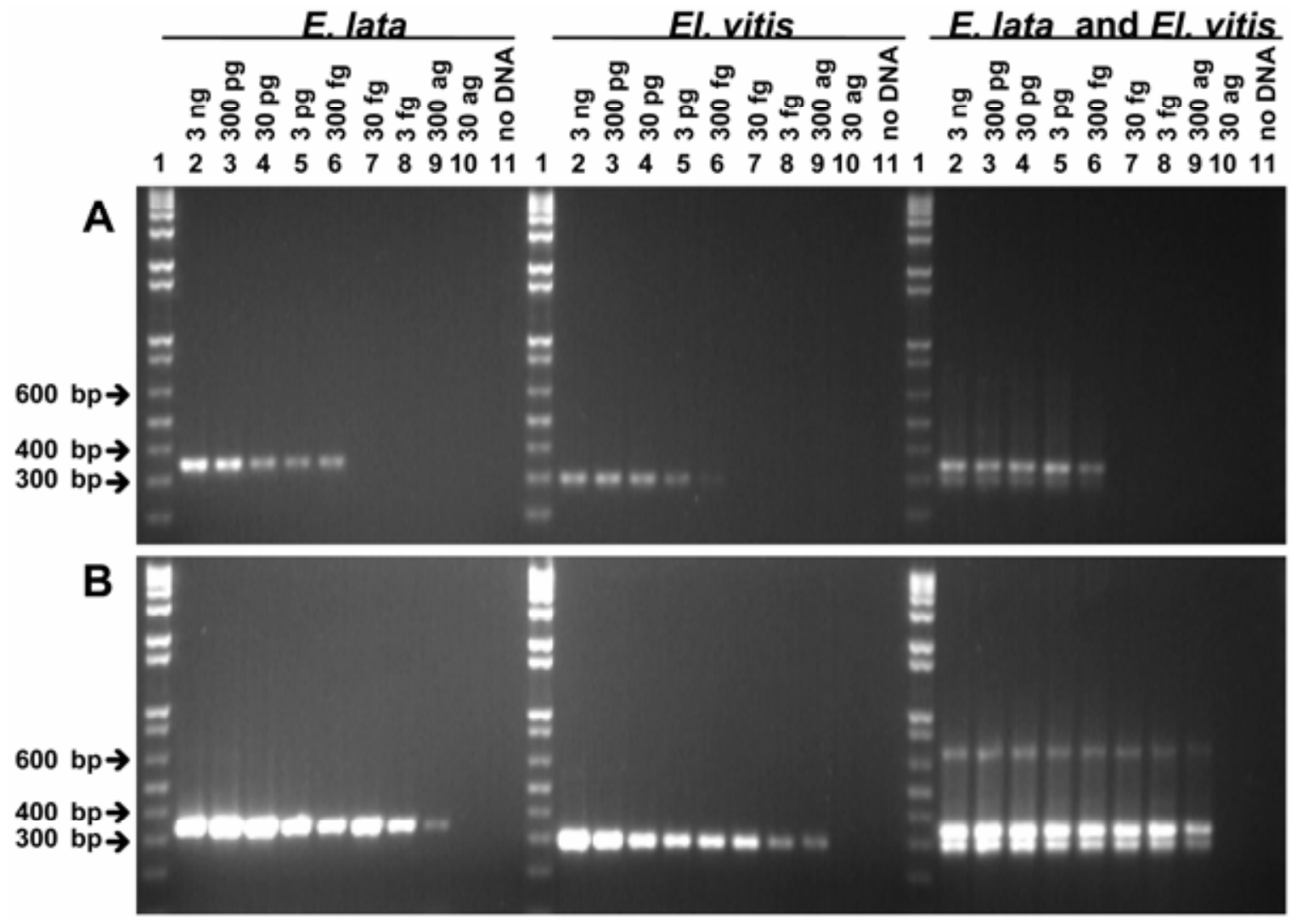

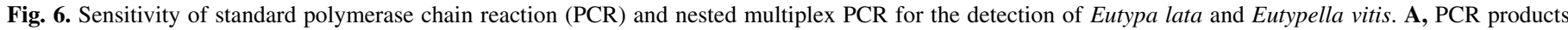

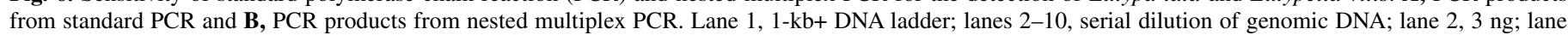
3, 300 pg; lane 4, 30 pg; lane 5, 3 pg; lane 6, 300 fg; lane 7, 30 fg; lane 8, 3 fg; lane 9, 300 ag; lane 10, 30 ag; lane 11, water control. 
Eutypa lata because primer sites that were conserved among all isolates of E. lata were rare, especially within the ITS2 region. This variation among isolates of $E$. lata could be a potential problem when using ITS-derived primers. With the primer set that we have developed, we were able to amplify the expected target from all the isolates tested, including those from California and Pennsylvania. We also have been able to successfully detect $E$. lata in wood from infected vines from Pennsylvania (data not shown). We did not observe any cross-reaction with DNA of other fungi even when the PCR was carried out with pure DNA extracted from mycelium. Whereas Rolshausen et al. (42) were unable to distinguish between E. lata and E. laevata with PCRRFLP, our species-specific primers did not amplify DNA extracted from E. laevata and may, therefore, be used to distinguish these two species. We expect that primers EL1 and EL4 will amplify E. lata found in North America but are not confident that they will amplify isolates from other grape-growing regions. Some isolates from Europe (AY787699 and AF099911) and Australia (AJ302446) have indels in the primer annealing sites that may result in a lack of amplification with the E. lata-specific primers. The reliability of the primer set needs to be confirmed with isolates from other parts of the world before being used for diagnostic purposes in these locations.

In this study, PCR assays with species-specific primers allowed for the identification and differentiation of both fungi from mycelial cultures in less than $3 \mathrm{~h}$ without the need for visual comparison with reference cultures. Furthermore, the primers were highly effective in detecting their respective target fungi in wood samples using a nested multiplex PCR approach, thus avoiding the time-consuming process of isolation and identification that would take weeks. Earlier attempts to amplify DNA directly from woody tissue using species-specific primers in a standard PCR reaction yielded weak or no products in the majority of the samples (data not shown). Amplification of the fungal DNA with universal fungal primers before using the speciesspecific primers greatly increased the sensitivity and effectiveness of the detection method. Even though the first round of amplification did not always yield visible bands on a gel, all but one of the samples yielded a product in the second round. Hamelin et al. (27) proposed that this increase in efficiency could be due to an increase in the ratio of target DNA to nontarget DNA from the first round of amplification. The first round of amplification also might be useful when the concentration of fungal DNA is very low or when PCR inhibitors are present in the plant tissue or extraction buffer, necessitating dilution of the sample. Using serial dilutions of pure fungal genomic DNA, we found that the multiplex nested PCR was at least 1,000-fold more sensitive than standard PCR. Another advantage of using a multiplex reaction is a reduction in the number of PCR samples that have to be run, saving the cost of PCR and gel components as well as labor.

Because we have found E. lata and Eutypella vitis on the same vine, there was a concern that the multiplex reaction would not amplify both products if present in the same sample, a problem that has been reported in multiplex reactions in other species $(5,27)$. When DNA of Eutypa lata and Eutypella vitis was present in equivalent amounts in a reaction, both PCR products were amplified, indicating no competition between the two amplicons. This work has significantly added to, and enhanced, the growing pool of literature pertaining to diagnostic techniques developed for Eutypa dieback. As we begin to understand the complexity of species involved in the co-colonization of grapevines with Eutypa lata, we will be able to refine and further develop molecular diagnostic techniques to characterize these interactions.

\section{ACKNOWLEDGMENTS}

This research project was funded in part by the United States Department of Agriculture Viticulture Consortium East and by the
National Grape Cooperative. We thank G. Adams, Department of Plant Pathology, Michigan State University, East Lansing, for research guidance; T. Holloway, National Grape Cooperative Inc., Westfield, NY, for assistance in locating vineyards with Eutypa dieback for sampling; B. Hed, Lake Erie Regional Grape Research and Extension Center, North East, PA, for providing E. lata and Fusarium oxysporum isolates and infected vine samples from Pennsylvania; D. Gubler and F. Trouillas, University of California, Davis, for providing isolates of Diatrypaceous fungi from California; and M. Ellis, Department of Plant Pathology, Ohio State University, Wooster, for providing Phomopsis isolates from Ohio.

\section{LITERATURE CITED}

1. Altschul, S. F., Gish, W., Miller, W., Myers, E. W., and Lipman, D. J. 1990. Basic local alignment search tool. J. Mol. Biol. 215:403-410.

2. Altschul, S. F., Madden, T. L., Schäffer, A. A., Zhang, J., Zhang, Z., Miller, W., and Lipman, D. J. 1997. Gapped BLAST and PSI-BLAST: a new generation of protein database search programs. Nucleic Acids Res. 25:3389-3402.

3. Bailey, A. M., Mitchell, D. J., Manjunath, K. L., Nolasco, G., and Niblett, C. L. 2002. Identification to the species level of the plant pathogens Phytophthora and Pythium by using unique sequences of the ITS1 region of ribosomal DNA as capture probes for PCR ELISA. FEMS Microbiol. Lett. 207:153-158.

4. Bluhm, B. H., Flaherty, J. E., Cousin, M. A., and Woloshuk, C. P. 2002. A multiplex polymerase chain reaction (PCR) assay for the differential detection of trichothecene- and fumonisin-producing species of Fusarium in cornmeal. J. Food Prot. 65:1955-1961.

5. Bourque, S. N., Valéro, J. R., Mercier, J., Lavoie, M.C., and Levesque, R. C. 1993. Multiplex polymerase chain reaction for detection and differentiation of the microbial insecticide Bacillus thuringiensis. Appl. Environ. Microbiol. 59:523-527.

6. Brown, A. E., Muthumeenakshi, S., Sreenivasaprasad, S., Mills, P. R., and Swineburn, T. R. 1993. A PCR primer specific to Cylindrocarpon heteronema for detection of the pathogen in apple wood. FEMS Microbiol. Lett. 108:117-120.

7. Butterworth, S. C. 2003. Eutypa dieback: Effects on growth and yield components, and diagnosis in 'Concord' grapevines. M. S. thesis, Michigan State University.

8. Carter, M. V. 1957. Eutypa armeniacae Hansf. \& Carter, sp. nov., an airborne vascular pathogen of Prunus armeniaca L. in southern Australia. Aust. J. Bot. 5:21-35.

9. Carter, M. V. 1988. Eutypa dieback. Pages 32-34 in: Compendium of Grape Diseases. R. C. Pearson and A. C. Goheen, eds. The American Phytopathological Society Press, St. Paul, MN.

10. Carter, M. V. 1991. The status of Eutypa lata as a pathogen. Monograph. Phytopathological Paper No. 32, International Mycological Institute, Egham, UK.

11. Carter, M.V., Bolay, A., and Rappaz, F. 1983. An annotated host list and biblography of Eutypa armeniacae. Rev. Plant Pathol. 62:251258.

12. Chamberlain, J. S., Gibbs, R. A., Ranier, J., Nguyen, P. N., and Caskey, C. T. 1988. Deletions screening of the Duchenne muscular dystrophy locus via multiplex DNA amplification. Nucleic Acids Res. 16:1114111165.

13. Chiocchetti, A., Bernardo, I., Daboussi, M. J., Garibaldi, A., Gullino, M. L., Langin, T., and Migheli, Q. 1999. Detection of Fusarium oxysporum f. sp. dianthi in carnation tissue by PCR amplification of transposon insertions. Phytopathology 89:1169-1175.

14. Cullen, D. W., Lees, A. K., Toth, I. K., Bell, K. S., and Duncan, J. M. 2000. Detection and quantification of fungal and bacterial potato pathogens in plants and soil. Bull. OEPP 30:485-488.

15. de Haan, L. A. M., Numansen, A., Roebroeck, E. J. A., and van Doorn, J. 2000. PCR detection of Fusarium oxysporum f. sp. gladioli race 1, causal agent of Gladiolus yellows diseases, from infected corms. Plant Pathol. 49:89-100.

16. DeScenzo, R. A., Engel, S. R., Gomez, G., Jackson, E. L., Munkvold, G. P., Weller, J., and Irelan, N. A. 1999. Genetic analysis of Eutypa strains from California supports the presence of two pathogenic species. Phytopathology 89:884-893.

17. Deswarte, C., Rouquier, P., Roustan, J. P., Dargent, R., and Fallot, J. 1994. Ultrastructural changes produced in plantlet leaves and protoplasts of Vitis vinifera cv. Cabernet Sauvignon by eutypine, a toxin from Eutypa lata. Vitis 33:185-188.

18. Duggal, A., Dumas, M. T., Jeng, R. S., and Hubbes, M. 1997. Ribosomal variation in six species of Fusarium. Mycopathologia 140:35-49.

19. Ellis, J. B., and Everhart, B. M. 1892. The North American Pyrenomycetes. Johnson Reprint Corporation, New York. 
20. Gardes, M., and Bruns, T. D. 1993. ITS primers with enhanced specificity for basidiomycetes-application to the identification of mycorrhizae and rusts. Mol. Ecol. 2:113-118.

21. Gariepy, T. D., Levesque, C. A., de Jong, S. N., and Rahe, J. E. 2003. Species specific identification of the Neofabraea pathogen complex associated with pome fruits using PCR and multiplex DNA amplification. Mycol. Res. 107:528-536.

22. Gendloff, E. H., Ramsdell, D. C., and Burton, C. L. 1983. Fluorescent antibody studies with Eutypa armeniacae, cause of dieback of grapes, Vitis labrusca. Phytopathology 73:760-764.

23. Glawe, D. A., and Jacobs, K. A . 1987. Taxonomic notes on Eutypella vitis, Cryptosphaeria populina, and Diatrype stigma. Mycologia 79:135-139.

24. Glawe, D. A., and Rogers, J. D. 1982. Observations on the anamorphs of six species of Eutypa and Eutypella. Mycotaxon 14:334-346.

25. Goodwin, S. B., Dunkle, L. D., and Zismann, V. L. 2001. Phylogenetic analysis of Cercospora and Mycosphaerella based on the internal transcribed spacer region of ribosomal DNA. Phytopathology 91:648-658.

26. Goodwin, S. B., Waalwijk, C., Kema, G. H. J., Cavaletto, J. R., and Zhang, G. 2002. The barley pathogen Septoria passerinii probably has an unobserved sexual cycle. (Abstr.) Phytopathology 92:S30.

27. Hamelin, R. C., Berube, P., Gignac, M., and Bourassa, M. 1996. Identification of root rot fungi in nursery seedlings by nested multiplex PCR. Appl. Environ. Microbiol. 62:4026-4031.

28. Hamelin, R. C., Bourassa., M., Rail, J., Dusabenyagasani, M., Jacobi, V., and Laflamme, G. 2000. PCR detection of Gremmeniella abietina, the causal agent of Scleroderris canker of pine. Mycol. Res. 104:527-532.

29. Hanlin, R. T., 1990. Illustrated Genera of Ascomycetes. Pages 82-85 in: Volume I. The American Phytopathological Society, St. Paul, MN.

30. Jordan, S., and Schilder, A. 2005. Eutypella vitis, a potential pathogen of grapevines in Michigan. (Abstr.) Phytopathology 95:S51.

31. Lardner R., Stummer B. E., Sosnowskip, M. R., and Scott, E. S. 2005. Molecular identification and detection of Eutypa lata in grapevine. Mycol. Res. 109:799-808.

32. LeComte, P., Peros, J. P., Blancard, D., Bastien, N., and Delye, C. 2000. PCR assays that identify the grapevine dieback fungus Eutypa lata. Appl. Environ. Microbiol. 66:4475-4480.

33. Lee, S. B., Milgroom, M. G., and Taylor, J. W. 1988. A rapid, high yield mini-prep method for isolation of total genomic DNA from fungi. Fungal Genet. Newsl. 35:23-24.

34. Moller, W. J., and Kasimatis, A. N. 1978. Dieback of grapevines caused by Eutypa armeniacae. Plant Dis. Rep. 62:254-258.

35. Molyneux, R. J., Mahoney, N., Bayman, P., Wong, R. Y., Meyer, K., and Irelan, N. 2002. Eutypa dieback in grapevines: differential production of acetylenic phenol metabolites by strains of Eutypa lata. J. Agric. Food Chem. 50:1393-1399.

36. Mostert, L., Halleen, F., Crous, P. W., and Creaser, M. L. 2004. Cryptovalsa ampelina, a forgotten shoot and cane pathogen of grapevines. Australas. Plant Pathol. 33: 295-299.

37. Munkvold, G. P., Duthie, J. A., and Marois, J. J. 1994. Reductions in yield and vegetative growth of grapevines due to Eutypa dieback. Phytopathology 84:186-192.

38. Pearson, R. C., and Burr, T. 1981. Eutypa dieback. Grape IPM Disease Identification Sheet No. 1. New York State Agricultural Experiment Station, Geneva.

39. Peros, J. P., and Berger, G. 1999. Diversity within natural progenies of the grapevine dieback fungus Eutypa lata. Curr. Genet. 36:301-309.
40. Peros, J. P., Berger, G., and Lahogue, F. 1997. Variation in pathogenicity and genetic structure in the Eutypa lata population of a single vineyard. Phytopathology 87:799-806.

41. Peros, J. P., This, P., Confuron, Y., and Chacon, H. 1996. Comparison by isozyme and RAPD analysis of some isolates of the grapevine dieback fungus, Eutypa lata. Am. J. Enol. Vitic. 47:49-56.

42. Pilotti, M., Gervasi, F., and Brunetti, A. 2005. Molecular identification of Fomitiporia mediterranea and Eutypa lata/Libertella blepharis in Platanus x acerifolia. J. Phytopathol. 153:193-202.

43. Price, T. V. 1973. Serological identification of Eutypa armeniacae. Aust. J. Biol. Sci. 26:389-394.

44. Rappaz, F. 1987. Taxonomie et nomenclature des Diatrypacées a asques octospores. Mycol. Helv. 2:286-648.

45. Rollo, F., Salvi, R., and Torchia, P. 1990. Highly sensitive and fast detection of Phoma tracheiphila by polymerase chain reaction. Appl. Microbiol. Biotechnol. 32:572-576.

46. Rolshausen, P. E., Mahoney, N. E., Molyneux, R. J., and Gubler, W. D. 2006. A reassessment of the species concept in Eutypa lata, the causal agent of Eutypa dieback of grapevine. Phytopathology 96:369377.

47. Rolshausen, P. E., Trouillas, F. P., and Gubler, W. D. 2004. Identification of Eutypa lata by PCR-RFLP. Plant Dis. 88:925-929.

48. Schilder, A. M. C., Butterworth, S. C., and Catal, M. 2003. Eutypa dieback: progression and detection of the pathogen in grapevines. (Abstr.) Phytopathology 93:S76.

49. Schmidt, O., and Moreth, U. 2002. Data bank of rDNA-ITS sequences from building-rot fungi for their identification. Wood Sci. Technol. 36:429-433.

50. Siebert, J. B. 2001. Eutypa: the economic toll on vineyards. Wines Vines 2001 (April):50-56.

51. Suga, H., Hasegawa, T., Mitsui, H., Kageyama, K., and Hyakumachi, M. 2000. Phylogenetic analysis of the phytopathogenic fungus Fusarium solani based on the rDNA-ITS region. Mycol. Res. 104:11751183.

52. Tey-Rulh, P., Philippe, I., Renaud, J. M., Tsoupras, G., De-Angelis, P., Fallot, J., and Tabacchi, R. 1991. Eutypine, a phytotoxin produced by Eutypa lata, the causal agent of dying-arm disease of grapevine. Phytochemistry 30:471-473.

53. Tredway, L. P., Covert, S. F., Gold, S. E., Stevenson, K. L., and Burpee, L. L. 2001. A PCR-based assay for mating type determination in Magnaporthe grisea. (Abstr.) Phytopathology 91:S203.

54. Trese, A. T. 1980. Epidemiological and etiological studies of Eutypa dieback of grape (Vitis labrusca L.) caused by Eutypa armeniacae. M.S. thesis, Michigan State University.

55. Trouillas, F. P., and Gubler, W. D. 2004. Identification and characterization of Eutypa leptoplaca, a new pathogen of grapevine in northern California. Mycol. Res. 108:1195-1204.

56. Weigle, T. H., and Muza, A. J., eds. 1997. 1998 New York and Pennsylvania Pest Management Recommendations for Grapes. Cornell Cooperative Extension, Ithaca, NY, and Penn State Cooperative Extension, University Park, PA.

57. White, T. J., Bruns, T., Lee, S. B., and Taylor, J. 1990. Amplification and direct sequencing of fungal ribosomal RNA genes for phylogenetics. Pages 315-322 in: PCR protocols: A Guide to Methods and Applications. M. A. Innis, D. H. Gelfand, J. J. Sninsky, and T. J. White, eds. Academic Press, San Diego, CA. 